\title{
Viral Hepatitis Infections in Chronic Kidney Disease Patients and Renal Transplant Recipients
}

\author{
Petr Urbánek \\ Department of Internal Medicine, First Medical Faculty, Charles University, and Central Military Hospital Prague, \\ Prague, Czech Republic
}

\section{Key Words}

Antiviral treatment $\cdot$ Chronic kidney disease $\cdot$ Dialysis • Hepatitis A virus $\cdot$ Hepatitis B virus $\cdot$ Hepatitis $C$ virus . Renal transplant recipient $\cdot$ Transmission modes $\cdot$ Virus transmission

\begin{abstract}
Within the last few decades, the incidence and prevalence of both hepatitis $B$ and $C$ infections have decreased among kidney disease patients. Significant advances have been made in the prevention of hepatitis $B$ and $C$ virus transmission in these high-risk populations; however, the transmission risk is still not negligible. Viral hepatitis infections represent a significant problem among kidney disease patients; patients on regular dialysis, as well as renal transplant recipients (RTRs) due to their epidemiological, virological, and clinical features. Chronic hepatitis B and $C$ have a strong impact on the clinical course of kidney disease as well as on the clinical course after kidney transplantation. The purpose of this review is to focus on the epidemiology, transmission modes, natural courses, and treatment options of hepatitis B and C infections in both chronic kidney disease patients and RTRs.
\end{abstract}

Copyright $\odot 2012$ S. Karger AG, Basel
(C) 2012 S. Karger AG, Basel

1420-4096/12/0356-0454\$38.00/0

Fax +4161306 1234

E-Mail karger@karger.ch

www.karger.com
Accessible online at: www.karger.com/kbr

\section{Hepatitis B}

\section{Hepatitis B Virus}

The currently available data suggest that more than half of the world population may have been hepatitis $B$ virus (HBV) infected at some time in the past. It is estimated that $>350$ million people throughout the world are chronically infected with HBV if assessed by the prevalence of hepatitis B surface antigen (HBsAg). Approximately 1 million deaths occur each year as a result of acute or chronic liver disease and hepatocellular carcinoma (HCC), which are attributed to this infection. The prevalence of HBsAg varies from 20\% in highly endemic areas to $0.1 \%$ in regions of low endemicity. The number of new HBV infections per year was calculated to be between 8,000 and 32,000 per year; and the total number of deaths resulting from end-stage liver disease or HCC calculated to be 5,000-6,000 [1]. In low-prevalence areas (such as Western Europe), the most important mode of transmission is the sexual route. Transmission mainly occurs in adolescence and mid-adulthood. In high-prevalence regions (Asia, prevalence $\geq 8 \%$ ), the main route is by vertical-perinatal transmission [2].

$\mathrm{HBV}$ is an important cause of hepatitis in patients with chronic kidney disease (CKD) who are on regular hemodialysis, as well as in renal transplant recipients (RTRs). 
Controlling the transmission of HBV infection in dialysis units is considered one of the major advances in the management of patients with end-stage renal disease [3]. The management of HBV infection in the dialysis population has made significant progress due to improvements within the last decade in both the diagnostic techniques as well as the options of antiviral therapies.

The prevalence of HBV infection among patients on long-term dialysis is low within dialysis units in western countries. The prevalence (measured as HBsAg positivity) ranges from 0 to $10 \%$ [4]. The spread of HBV infection within dialysis units has been effectively prevented since the 1970s, when infection control procedures (including vaccination) were implemented into routine practice in dialysis centers. Despite this, HBV outbreaks continue to be reported, even in the developed world [5]. In the lessdeveloped parts of the world, the epidemiological situation is not as well known. In single-center surveys, the HBsAg prevalence ranges from 2 to $20 \%[6,7]$. Some explanations for such prevalence are obvious: a higher HBsAg prevalence in the general population; not very strict adherence to standard precautions and routine hemodialysis precautions; the absence of HBV vaccinations, and, of course, the lack of financial resources [8].

\section{The HBV Genome}

HBV belongs to the family Hepadnaviridae. It has a double-stranded circular DNA genome that replicates through an RNA intermediate [9]. Electron-microscopically, the virion is visible as a particle $50 \mathrm{~nm}$ in diameter, having an outer envelope (HBsAg) and an inner nucleocapside (hepatitis B core antigen, $\mathrm{HBcAg}$ ) [10].

The genome, which is located in the complete virion, consists of a partially double-stranded DNA. The HBV genome is relatively small among human viruses, having a length of approximately 3,200 bp. Four partially overlapping open reading frames (ORFs) can be identified within the genome. They are named $\mathrm{P}$ (polymerase), $\mathrm{S}$ (surface), C (core), and X (HBx protein). The S and C regions are elongated by the pre-Cand pre-S regions. Translation of the polypeptide chain that contains pre- $\mathrm{C}$ and $\mathrm{C}$ results in a secretory protein termed $\mathrm{HBeAg}$, which is structurally and functionally different from the $\mathrm{C}$ protein, which is the product of the $\mathrm{C}$ region. $\mathrm{C}$ protein $(\mathrm{HBcAg})$ surrounds a partially double-stranded circular HBV DNA. Translation of the pre-S1, pre-S2, and S-ORF leads to expression of the large subunit of HBsAg; translation of only the pre-S2 and S-ORF results in the middle subunit of HBsAg, and expression of the S-ORF alone creates the small subunit of HBsAg.

Viral Hepatitis Infections in CKD
Eight HBV genotypes have been described. Genotype A is most prevalent in the United States and in Northern Europe, genotypes B and C are prevalent in Asia, and genotype $\mathrm{D}$ is mostly found in the Mediterranean region $[11,12]$. The clinical relevance of each particular genotype has not yet been fully elucidated. Chronic HBV genotype $\mathrm{C}$ infection seems to have both a poorer prognosis and higher risk of progression to cirrhosis and HCC than does genotype B [13].

Viral replication of $\mathrm{HBV}$ is unique among DNA viruses. The replication occurs in the cytoplasm of hepatocytes and is a very complicated process, which uses RNAdependent DNA polymerase (reverse transcriptase) in multiple steps and finally produces a new molecule of HBV-DNA. This reverse transcriptase activity is a key enzyme in viral replication. It is prone to make many substitutions - mutations in the new HBV-DNA strand; therefore, these strands will differ from the mother strand. Some of these different strands have strong clinical impacts. Two groups of mutations are used to distinguish: (1) naturally evolving mutations, e.g. pre-C or basal core promoter (BCP) mutations which lead to the selection of viral strands which are not able to produce $\mathrm{HBeAg}$ in the replicative phase of HBV infection, and (2) mutations induced by antiviral therapy, which lead to resistance to specific antiviral drugs [14].

$\mathrm{HBV}$ is a non-cytopathic virus. Liver tissue injury is a consequence of immune-mediated processes [15]. Viral clearance is mediated by both cytopathic and noncytopathic mechanisms. Most immunocompetent adults will develop transient infections after being exposed to HBV. Such acute infections may or may not be accompanied by symptoms, including jaundice. However, in a proportion of healthy adults ( $~ 5 \% ; 2 \%$ women and $7 \%$ men), chronic infection (infection lasting $>6$ months) may evolve as a result of the failure of the host's immune response [15]. Chronic infection more often develops in newborns (90\%), children (30\%), as well as in immunodeficient persons (including patients with CKD or dialyzed patients) [16].

\section{Diagnostic Tests}

Diagnostic serologic tests and their interpretation are shown in table 1. HBsAg is the first detectable marker after transmission of the virus. The incubation period can be up to 6 months. HBcAg is only present in hepatocyte nuclei, but corresponding antibodies circulate in the blood as antibodies to $\mathrm{HBcAg}$. During acute infection, anti- $\mathrm{HBc}$ is the predominant $\mathrm{M}$ class immunoglobulin. If HBsAg persists for $>12$ weeks in the serum, the hepatitis $\mathrm{B}$ e antigen (HBeAg) and viral DNA (HBV-DNA) should 
Table 1. Interpretation of serologic results

\begin{tabular}{lllll}
\hline HBsAg & $\begin{array}{l}\text { Total } \\
\text { anti-HBc }\end{array}$ & $\begin{array}{l}\text { IgM } \\
\text { anti-HBc }\end{array}$ & Anti-HBs & Interpretation \\
\hline- & - & NA & - & susceptible; offer vaccination \\
\hline- & + & NA & + & immune due to natural infection \\
\hline- & - & NA & + & immune due to hepatitis B vaccination \\
\hline+ & + & - & - & chronic HBV infection \\
\hline+ & + & NA & - & \begin{tabular}{l} 
acute HBV infection \\
\hline-
\end{tabular} \\
\hline+ & & - & $\begin{array}{l}\text { (1) resolved infection (most common) } \\
\text { (2) false-positive anti-HBc; susceptible } \\
\text { (3) 'low-level' chronic infection } \\
\text { (4) resolving acute infection }\end{array}$ \\
\hline
\end{tabular}

be tested. These markers reflect the level of viral replication within the liver tissue of the host. As the acute infection resolves, the level of viral replication declines, anti$\mathrm{HBc}$ IgM declines, while the IgG anti-HBc level increases and persists for a long time.

After resolution of an acute HBV infection (when HBsAg disappears from the serum), antibodies to surface antigens (anti-HBs) become detectable. Anti-HBs antibody is a neutralizing, seroprotective antibody. Patients with post-infective immunity have both detectable anti-HBs and anti-HBc antibodies. The anti-HBs titer tends to decline with years; therefore, in some patients, only anti-HBc antibodies remain detectable after $\mathrm{HBV}$ infection. Anti-HBc IgG is the most durable marker of prior infection; thus, it is usually classified as a marker of HBV exposure [17]. Immunity after vaccination is characterized by the presence of anti-HBs, along with the absence of anti-HBc.

If $\mathrm{HBs} \mathrm{Ag}$ persists for $>6$ months, the acute $\mathrm{HBV}$ infection has progressed to a chronic infection. Chronic HBV infection is a dynamic state based on interactions between HBV, hepatocytes, and the immune system of the host [18]. The natural course of chronic HBV infection can be divided into four phases: immune tolerance, immune clearance, residual inactivity, and reactive immune clearance. The latter can be viewed as a variant of the immune clearance phase, which is given by the emergence of $\mathrm{HBeAg}$-negative strands (pre-C and BCP mutations). The majority of immunosuppressed patients who are chronically infected with HBV are diagnosed in the immune-tolerant or inactive phases (table 1). Serum alanine aminotransferase (ALT) is normal (or nearly normal) in such phases, but the viral load is high (serum HBV-DNA $>2 \times 10^{2}$ to $2 \times 10^{7} \mathrm{IU} / \mathrm{ml}$ ) in the immune-tolerant phase. In the inactive phase, HBV-DNA is rather low $\left(10^{2}-10^{4} \mathrm{IU} / \mathrm{ml}\right)[18]$.

\section{Natural History of HBV Infection in CKD and RTR Patients}

To understand the natural history of HBV infection in CKD or dialysis patients is a complicated issue. The natural course of the disease is characterized by morbidity and mortality due to disease, as well as by the incidence of well-defined complications, which may be attributed to the disease. Morbidity and mortality in chronic hepatitis $\mathrm{B}(\mathrm{CHB})$ are given by the incidence of liver cirrhosis, by the risk of its vascular or metabolic decompensation, and by the incidence of HCC. Furthermore, the natural course denotes the course of untreated disease. It is not so easy to fulfill these requirements with $\mathrm{CHB}$ in either CKD or dialysis patients.

Our knowledge on the natural course of hepatitis B remains poor in CKD or dialysis patients. CHB is usually a slowly progressing disease, and the life expectancy of patients on regular long-term dialysis is shorter than would be needed for the development of all the consequences of hepatitis B. There is only limited information on the liver histology, too. Transcutaneous liver biopsy is often considered to be contraindicated in CKD patients (or even dialysis patients) due to platelet dysfunction and impaired blood coagulation in uremia. Transjugular liver (and kidney) biopsy seems to be a reasonable option; unfortunate- 
ly, however, it is not routinely available [19]. Furthermore, a lot of oral antiviral agents are now licensed for use in $\mathrm{CHB}$, even in $\mathrm{HBV}$-infected dialysis patients, creating a limitation in our ability to obtain information on the natural (e.g. untreated) course of CHB in CKD patients. Leaving patients untreated, if the indication for treatment is clear and well defined, is recognized as an unethical approach; especially when there is an efficient treatment available, and the treatment is capable of preventing the consequences of diseases such as HCC [20,21].

Only $3 \%$ of dialyzed patients are diagnosed with liver cirrhosis (from multiple etiologies); however, the death rate among them is $35 \%$ higher than in non-cirrhotic patients [20]. Maisonneuve et al. [22] found the risk of HCC significantly higher in dialysis patients when compared to the general population; however, this was linked to the prevalence of HBV (and hepatitis C virus, HCV), which is also higher in the dialysis population than in the general population. Factors associated with rapid progression of HBV-related liver disease include co-infections (HCV/HIV), alcohol abuse, and immunosuppression. Immunosuppression was recognized as a negative factor, particularly after renal transplantation (RT). The course of HBV-related liver disease seems to be more aggressive after RT than for patients on long-term dialysis. Due to either immunosuppression or low activity of cytotoxic $\mathrm{T}$ lymphocytes, HBV replication increases.

In 1996, a group of French authors [23] reported on a large cohort study among $151 \mathrm{HBsAg-positive} \mathrm{RTRs.}$ They found significantly lower spontaneous clearance rates of HBsAg (0.1\%), HBeAg (3\%), and HBV DNA (3\%) compared with the general population. Furthermore, this study described a significantly higher rate $(30 \%)$ of persistent replication and $\mathrm{HBeAg}$ reappearance among RTRs compared with the general population. Degos et al. [24] have demonstrated high rates of reactivation of HBV replication among RTRs, which were initially HBV-DNA negative (92\%). Of those patients initially HBV-DNA positive, 55\% had a significantly higher HBV-DNA level at the end of the follow-up. Among their patients, Tsai et al. [25] found a similar profile (HBV-DNA initially positive and significantly higher replication at the end of the follow-up), with a high incidence of liver cirrhosis (67\%).

For similar reasons as among CKD and dialysis patients, our information on liver histology among RTRs is limited. Up to the present, the largest study focusing on this issue was the study by Fornairon et al. [23] published in 1996. They performed 310 liver biopsies on $131 \mathrm{HBsAg-}$ positive RTRs. Of these patients, 101 had two or more biopsies. At the time of transplantation, a normal histol- ogy finding was found in 39\%; $61 \%$ of the patients had different forms of chronic hepatitis (they used the former nomenclature for persistent hepatitis/chronic active hepatitis, etc.). After a mean interval of 66 months, liver histology deterioration was observed in $85 \%$ of 101 patients with serial liver biopsies. Liver cirrhosis was recorded in $28 \%$ of them. Only $6 \%$ showed a normal histology in the second biopsy. Subsequently, these results were confirmed by other investigators but in smaller cohort studies [26].

Reactivation of HBV infection can also occur in patients that are HBsAg negative, with anti-HBs and anti$\mathrm{HBc}$ antibodies being positive at the time of transplantation. If the anti-HBs antibody titer is low (e.g. not protective), de novo HBV infection may be another explanation for the signs of active (acute) HBV infection [24, 27]. In these cases, it is very difficult (often impossible) to distinguish between true reactivation and a new infection. Virological testing may be helpful (genotyping/sequencing); however, from the clinical/therapeutic point of view, such complicated procedures are questionable and likely provide no cost benefits. In some cases after RT, HBV reactivation may lead to a distinct form of hepatitis called fibrosing cholestatic hepatitis [27]. The prognosis of this disease is usually poor. Fibrosing cholestatic hepatitis has repeatedly been described consequent to immunosuppressive therapy administered to patients with unrecognized chronic HBV infection (patients being HBsAg positive, HBV-DNA negative, or with low viremia). It is likely that the highest risk of HBV reactivation is in those patients treated by anti-CD20 antibodies [28].

The survival rate and mortality are always reliable end-points in the natural course of a disease. The studies available in the literature present contradictory information depending on their design, especially the length of the follow-up and period of their origination. Some initial studies published in the late 1980s or 1990s, which focused on a shorter survival (mostly 5 years), failed to show a significant difference between HBsAg-positive and -negative RTRs. Therefore, a 5-year survival seems not to be influenced by the HBsAg status among RTRs $[29,30]$. However, the difference in the survival rate is apparent in studies with longer follow-ups. In 1999, Mathurin et al. [31] reported better 10-year survival among HBV non-infected RTRs. They observed a 10 -year survival rate of $80 \pm 3 \%$ among HBsAg-negative patients and $55 \pm 6 \%$ among HBsAg-positive recipients. Such results were confirmed by Lee et al. [32]. These authors found a higher 10-year survival rate in HBsAg-negative RTRs than in HBsAg-positive patients (83 vs. $51 \%$, p < 
0.005). HBV infection was identified as an independent risk factor for mortality using multivariate analysis. A meta-analysis performed by Fabrizi et al. [33], who analyzed $>6,000$ patients, indicated that HBsAg positivity is an independent risk factor for death in RTRs (relative risk, RR: $2.49, \mathrm{p}<0.0001)$. Mortality due to liver cirrhosis and $\mathrm{HCC}$ were found to be responsible for this result. Several studies have shown that the risk of cirrhosis, HCC, and mortality increases proportionally with increasing serum HBV-DNA level, irrespective of the phase of the disease (HBeAg positive or $\mathrm{HBeAg}$ negative), starting with at least 10,000 copies $/ \mathrm{ml}(\sim 2,000 \mathrm{IU} / \mathrm{ml})[18,34]$. These data were obtained in an HBsAg-positive general population; however, if such results could also be reproduced in CKD, dialyzed patients, or RTRs is not known at present. As mentioned previously, Tsai et al. [25] found a significant correlation between high serum HBV-DNA levels and the development of liver cirrhosis among RTRs. In that study, HBV replication was found to be enhanced by the presence of $\mathrm{BCP}$ as well as the pre- $\mathrm{C}$ mutations in the viral genome (HBeAg-negative variant). The significance of an accumulation of HBV-mutant populations for the development of liver cirrhosis and end-stage liver disease after RT was also confirmed in the study by Preikschat et al. [35].

\section{Immune Response in CKD and Dialysis Patients}

When compared with the general population, one additional parameter is undoubtedly influencing the natural course of $\mathrm{HBV}$ disease in $\mathrm{CKD}$ and dialysis patients. End-stage renal disease is accompanied by an impaired immune system, leading to high susceptibility to many viral and bacterial infections. These immunological disturbances are very complex, affecting both acquired as well as innate immunity. An impaired immune response is one explanation for the differences between the consequences of HBV exposure of an immunocompetent adult host and those of CKD or dialysis patients. The chronic rate among immunocompetent hosts is $\sim 5 \%$; among CKD or dialysis patients it is $\geq 60 \%$ [36]. The differences in the clinical course of the disease are likely the result of the deficiency in CD8-cytotoxic and CD4 helper T lymphocytes, the functions of which are crucial in the destruction of HBV-positive hepatocytes and for B-lymphocyte antibody production [37]. In experimental studies, it has been shown that enterotoxin B-induced ligation between a major histocompatibility complex and T-cell receptors leads to reduced proliferation of T lymphocytes and chain phosphorylation [38]. In their studies, Girndt et al. [39-41] found that acquired immunity disturbances also include a low expression of many adhesion molecules, including ICAM-1 (intercellular adhesion molecule-1), reduced expression of CD80/CD86 receptors in antigen-presenting cells, and finally altered expression of CD28 in T lymphocytes. Not only the antigen-presenting cells, but also T-lymphocyte interactions are impaired in $\mathrm{CKD}$ and dialysis patients. Mechanisms of the alteration in adaptive immunity also include: increased $\mathrm{T}$ and $\mathrm{B}$ cell apoptosis, reduced T-/B-cell interactions by increased levels of CD40 molecules, impairment in calcium kinetics in lymphocytes, and impaired differentiation of naive CD4 lymphocytes to type-1 T helper cells (Th1) [42-45].

\section{Measures to Prevent HBV Spread in Hemodialysis Units}

There are three stages of preventive measures of HBV spread within hemodialysis units:

(1) The standard precautions against the transmission of any blood-borne infection (HBV, HCV, and HIV) represent the basis of all preventive methods. Each of these precautions should be very strictly applied. A separate hemodialysis room, exclusively designated for HBV-positive patients, seems to be a controversial issue; however, this has been recommended by the Centers for Disease Control and Prevention since $2001[8,46]$. HBV particles are usually found in high titers in the blood of patients on hemodialysis, and as HBV has been proven potentially infectious for $>1$ week, there is the real risk of transmission from small amounts of blood, or even from infected surfaces that may appear to be clean. In comparison, the $\mathrm{HCV}$ and HIV viruses are less infectious: HCV survives in the environment for a shorter time, and HIV cannot survive in the environment $[47,48]$. The risk of HBV transmission after a needle stick injury is obviously given by the serological status of the source, specifically of its HBV-DNA level/viral load. Repeatedly, it has been found that the risk of HBV transmission is $\sim 6 \%$ if the source is $\mathrm{HBeAg}$ negative (usually a low viral load) and $>30 \%$ if the source is HBeAg positive (e.g. a high viral load) [49].

(2) The universal vaccination of CKD patients, patients on regular dialysis, and all the staff of the hemodialysis unit against $\mathrm{HBV}$ is highly recommended [50]. Vaccination of CKD patients has been demonstrated to be a very effective preventive measure as vaccinated patients have a 70\% lower likelihood of developing hepatitis B and chronic HBV infection compared with non-vaccinated persons [51]. On the other hand, seroconversion rates in response to $\mathrm{HBV}$ vaccination are poor in the hemodialysis population compared with the general population (40-70 vs. 97\%) [52]. Impaired acquired immunity in he- 
modialyzed patients explains this poor response to active vaccination. Many factors are involved: inadequate dialysis, anemia, malnutrition, decreased immunoglobulin production, diminished interleukin-2 secretion by $\mathrm{T}$ lymphocytes, and impaired macrophage function have been found to be the most important $[41,53,54]$. Recently, Eleftheriadis et al. [55] found a correlation between high levels of indoleamine 2,3-dioxygenase and an inadequate response to $\mathrm{HBV}$ vaccinations. Indoleamine 2,3-dioxygenase levels among dialyzed patients were twice as high in non-responders than they were in responders to the vaccinations. Many clinical studies have investigated the predictors of seroconversion to HBV vaccination, and positive correlations were found with age, weight, albumin level, and male gender [56, 57]. Anti$\mathrm{HCV}$ reactivity and diabetes were found to be negative predictors of a response [58, 59].

Several studies found a better response to vaccination among patients with CKD before the initiation of dialysis therapy. The largest paper on this topic was published by DaRoza et al. [60] in 2003. Among their group of 165 patients, with a median estimated glomerular filtration rate (GFR) of $20 \mathrm{ml} / \mathrm{ml}$, the authors achieved an $82 \%$ seroconversion rate to HBV vaccination. The level of GFR has been proven to be an independent predictor for seroconversion by multivariate analyses. The model also confirmed that older patients, as well as patients with diabetes, were less likely to seroconvert. Univariate comparisons did not find any significant differences (seroconverters vs. non-seroconverters) for hemoglobin, erythropoietin use, albumin level, urea, cholesterol, or intact parathyroid hormone. Based upon these data, the initial HBV vaccination should be performed as soon as possible in the course of kidney disease.

The standardized recommended (and even cost-effective) vaccination schedule for CKD or hemodialyzed patients consists of the intramuscular administration of 40 $\mu \mathrm{g}$ of recombinant vaccine (double the dose for the general population) at 0,1 , and 6 months [61]. The seroprotective titer of anti-HBs antibody is $10 \mathrm{IU} / \mathrm{l}$. All three doses of vaccine should be repeated in non-responders to the first vaccination (a nonresponse is defined as an anti-HBs antibody titer $<10 \mathrm{IU} / \mathrm{ml} \mathrm{1-2} \mathrm{months} \mathrm{after} \mathrm{the} \mathrm{last} \mathrm{dose}$ of the initial vaccination) [62]. In responders to the initial vaccination, only one booster dose of the same vaccine should be administered if their anti-HBs decrease to $<10$ $\mathrm{IU} / \mathrm{ml}[63]$.

(3) The final stages of HBV prevention are the measures after exposure. The preventive measures are dependent on the anti-HBs titer of the exposed person. If the exposed person is proven to have anti-HBs $>10$ IU/l providing seroprotection, then no other measures are required. For those vaccinated individuals with anti-HBs $\leq 10 \mathrm{IU} / \mathrm{ml}$, then 1 dose of HBV immunoglobulin (HBIg) at a dose of $0.6 \mathrm{mg} / \mathrm{kg}$ of body weight, as well as 1 dose of recombinant vaccine is indicated. For persons who have never been vaccinated with anti-HBs $\leq 10 \mathrm{IU} / \mathrm{ml}$, the administration of HBIg and the immediate initiation of active vaccination are required. Finally, for those non-responders to 2 complete series of vaccinations, 2 doses of HBIg are indicated [50].

\section{Antiviral Therapy in CKD and Hemodialyzed Patients}

The current recommendations for the initiation of antiviral therapy in CKD and dialysis patients are based upon similar factors as they are for the general population. The most important parameter in this regard seems to be the viral replication level (e.g. the serum HBV-DNA level, measured by real-time polymerase chain reaction, PCR). The critical level for therapy initiation has been proven to be $2,000 \mathrm{IU} / \mathrm{ml}$. In some cases, the therapeutic decision should not be based on the HBV-DNA level alone. Additionally, the severity of liver disease should be considered, and the antiviral therapy should only be initiated if significant fibrosis or necroinflammatory activity is present [64]. Therefore, antiviral therapy should be initiated in $\mathrm{HBeAg}$-positive as well as in HBeAg-negative disease only if HBV-DNA $\geq 2,000 \mathrm{IU} / \mathrm{ml}$; therefore, HBV-DNA should be tested annually or in case of any unexplained ALT elevation [65]. In HBeAg-negative disease, the replication may be present due to mutations in the $\mathrm{BCP}$ or pre-C regions of the HBV genome [66]. These mutations block the secretion of $\mathrm{HBeAg}$ into the serum of the infected individuals.

The ideal objective of the treatment (which is difficult to achieve) is the seroconversion to anti-HBs. This status is called 'closest to cure'; as at the molecular level, HBV infection is an incurable disease because cccDNA (intermediate to the HBV replication) persists in the hepatocytes of every HBV-exposed person for their entire lives. The real aim of the treatment, which is achievable by the current treatment options, is the long-term suppression of HBV replication (e.g. decrease in the serum HBV-DNA levels).

CKD and dialyzed patients represent a very special population due to their impaired immunity, many comorbidities, and their limited life expectancy. On the other hand, our therapeutic options are also limited [67]. Interferon (IFN)- $\alpha$ therapy has repeatedly been found 
less effective than in the general population among CKD or dialyzed patients. Immunomodulative therapy results in many side effects, which may be highly undesirable in this specific population. Side effects such as anemia, leukopenia, weight loss (due to appetite loss), and even cachexia represent the main limitations of IFN use in CKD or dialyzed patients. In RTRs, IFN therapy is associated with a higher incidence of rejection; therefore, in this setting, IFN is contraindicated.

The treatment of choice in $\mathrm{CKD}$, dialyzed patients, and RTRs are the nucleoside or nucleotide analogues, which have almost no serious side effects. All of these drugs inhibit viral RNA-dependent DNA polymerase via the chain termination mechanism. Therefore, the result of their administration is a rapid decrease in serum HBVDNA, which may even become undetectable. All of these analogues should be administered in a reduced dose depending on GFR; in those patients on regular hemodialysis, they should be administered after each procedure. In HBeAg-positive disease, the therapy should be discontinued 3-6 months after HBeAg loss or after seroconversion to anti-HBe. The indication for treatment cessation in $\mathrm{HBeAg}$-negative disease is not known if the loss of HBsAg has not been achieved [54].

A viral resistance may develop after administration of almost every analogue. The higher the generation of the analogue, the lower is the risk of resistance and the development of later resistance. For example, among the general population, the resistance rate to lamivudine after 4 years of treatment is $70 \%$. The resistance rate is much lower with the newer analogue entecavir, only $1.2 \%$ after 4 years among naive patients (patients treated by entecavir as a first-line treatment), and even $0 \%$ for tenofovir [68]. These two drugs represent the new group of analogues with a high genetic barrier to resistance. Entecavir and tenofovir should be preferred if long-term treatment is to be very likely. Unfortunately, in the literature, there is a lack of data on the development of viral resistance among CKD, hemodialyzed patients, or transplant recipients. Only a very few observational studies using lamivudin have yet been published $[69,70]$.

\section{Hepatitis C}

\section{Hepatitis $C$ Virus}

$\mathrm{HCV}$ was first isolated and described in 1989 [71]. It is considered the leading cause of chronic hepatitis, endstage liver cirrhosis, and HCC. Worldwide, it affects $\sim 3 \%$ of the human population [72]. HCV is also the leading cause of liver transplantation; responsible for $>50 \%$ of all adult liver transplantations in western countries. The overall geographical prevalence of HCV is different. In some regions, there is still a lack of sufficient data, but the prevalence ranges from $<1.0 \%$ in Northern Europe to $>2.9 \%$ in Northern Africa. The lowest prevalence (0.01$0.1 \%$ ) has been reported from the United Kingdom and Scandinavia, with the highest prevalence (15-20\%) reported from Egypt [73].

\section{The HCV Genome}

$\mathrm{HCV}$ is an RNA virus, the only member of the genus Hepacivirus within the Flaviviridae family. The virus has a single-stranded RNA genome of $\sim 10 \mathrm{~kb}$ of nucleotides; with a genome consisting of several regions coding structural $(\mathrm{C}, \mathrm{E} 1$, and $\mathrm{E} 2)$ and nonstructural viral proteins (NS2-NS5). The translational product is a single large precursor protein. This large polyprotein is cleaved into functional structural and nonstructural proteins within the viral replication cycle in the hosting cell. The RNAdependent RNA polymerase, which plays the key role in viral replication, is located in the NS5 region of the genome [74].

$\mathrm{HCV}$ is a very heterogeneous virus. It exists in 6 major genotypes; within each genotype, several (or even many) subtypes may be distinguished. Genotypes and subtypes show geographically different distributions. Genotype 1 is the most prevalent genotype in Europe and the United States; in Central and Western Europe, the most prevalent subtype is $1 b$ [75].

\section{Modes of Transmission}

The modes of transmission have changed over time, and differ between countries. Before the 1990s, when screening antibody tests were implemented for the evaluation of blood donors, HCV was mostly transmitted by blood and blood products. Soon after this more efficient screening was established, the incidence of post-transfusion hepatitis $\mathrm{C}$ declined. Today, the transmission risk has been estimated at $0.1-2.33$ per million transfusions [76]. Other risk factors for transmission include solid organ transplantation, hemodialysis, occupational exposure (needlestick injury), intravenous drug use, having sex with an infected person, multiple sexual partners, or by perinatal transmission [72]. Sexual transmission can occur in cases of vaginal mucosal damage, among commercial sex workers, or in people with multiple sexual partners. Overall, the sexual and perinatal transmissions are quite rare, with $<10 \%$ of the infected persons acquiring their infections by these routes. Transmission can 
also occur through tattooing and body piercing if inadequately sterilized devices are used; the same cause and routes play a role in transmission via folk and traditional medical procedures. In addition to these well-defined routes of HCV spread, there is still a substantial proportion $(20-50 \%)$ of infected persons without any known risk factor for transmission. These patients likely acquired HCV through some very rare routes of transmission, such as surgical or dental procedures, health care procedures in the past using non-disposable devices, accidental needlesticks, or sexual or household transmissions from persons who were not known to be infected.

In developed countries, almost $60 \%$ of new $\mathrm{HCV}$ transmissions (after HCV screening among blood donors) are among intravenous drug users [72]. The overall $\mathrm{HCV}$ incidence is declining, mainly due to approved screening programs in the healthcare system (disposable devices and accessories, treatment of hemophiliacs with recombinant coagulant factors), as well as improved hygiene practices in high-risk settings such as hemodialysis [77].

\section{HCV Diagnostic Methods}

Serological tests identify anti-HCV antibodies, currently mostly used by the third generation of EIA tests. These assays are recommended for screening in populations at risk of $\mathrm{HCV}$ transmission. This generation of tests is able to detect anti-HCV antibodies 4-6 weeks after transmission. The specificity of anti-HCV detection in blood donors is $99.95 \%$, while the sensitivity in patients with chronic liver disease was estimated to be $98.9 \%$. All positive anti-HCV results (suggesting active HCV infection) must be confirmed by the detection of HCV-RNA in serum or whole blood. PCR assays generally surpassed the recombinant immunoblot testing (not routinely used at present). HCV-RNA levels (viralload) should be expressed in standardized international units per milliliter. The vast majority of molecular tests currently used to detect HCVRNA are quantitative real-time PCR-based assays that are highly sensitive, e.g. with a low detection limit (10-50 IU/ $\mathrm{ml}$ ). Many commercially produced assays are available on the market (e.g. Cobas Ampliprep/Cobas TaqMan System, and Abbott RealTime HCV) [78]. PCR techniques are also used for HCV genotyping. HCV genotype and viral load are important viral factors for determining the type and length of the antiviral treatment.

\section{Mixed Cryoglobulinemia}

Mixed cryoglobulinemia (MC) is one of the most common extrahepatic manifestations of $\mathrm{HCV}$ infection, which may present as kidney disease. MC is defined as the presence of circulating immunoglobulins that reversibly precipitate in the serum. Type I MC is characterized by the presence of monoclonal immunoglobulins (IgG); this specific type is not associated with HCV infection. Type II MC is characterized by the presence of polyclonal IgG and monoclonal IgM with rheumatoid factor activity. Type III MC has polyclonal IgG and polyclonal IgM with rheumatoid factor activity. Except in HCV infections, types II and III MC may also associate with HIV or HBV infections. The hypothesis that with an increasing duration of an $\mathrm{HCV}$ infection, type III MC progresses to type II MC is now widely accepted. This is based on previous observations that the apparent duration of $\mathrm{HCV}$ infection in patients with type II MC was twice as long as among patients with type III MC [79]. There is a very close-fitting relationship between type II MC (monoclonal IgM cryoglobulin as a sign of monoclonal B-cell proliferation) and lymphoproliferative disorders, primarily non-Hodgkin's lymphoma [80].

The prevalence of MC increases with the duration of the HCV infection [79]. Interestingly, type II MC is associated with a low prevalence of liver cirrhosis [81]. The prevalence of HCV among patients with clinically symptomatic MC reaches 70-90\% [82, 83]. On the other hand, only a minority of patients with cryoglobulinemia will develop extrahepatic clinical manifestations. A metaanalysis of $>2,300$ patients with chronic HCV infection found a $44 \%$ prevalence of cryoglobulinemia [83].

The clinical manifestation of MC involves the skin with leukocytoclastic vasculitis (palpable purpura), arthralgia, peripheral neuropathy, Sicca syndrome, and Raynaud's phenomenon. The renal manifestation of MC is usually type I membranoproliferative glomerulonephritis (MPGN), which is strongly associated with type II MC. It may present with proteinuria, microscopic hematuria, renal insufficiency, and hypertension. The prevalence of MPGN in type II MC has been reported in one Japanese study to be as high as $50 \%$. Only $12 \%$ of these MPGN were clinically apparent [84]. The prevalence of HCV infection among patients with MPGN varies. In Japan, about $60 \%$ of all MPGN patients are HCV positive, while in the USA the prevalence in the same group is $10-20 \%$ [85-87].

MPGN may be the presenting symptom of HCV infection. Renal biopsies in MPGN are characterized by a monocyte infiltrate, double-contour basement membranes, and eosinophilic intraluminal deposits. Subendothelial deposits consist of IgG, IgM, and complement in the glomeruli [88]. These are likely the main pathophysiological mechanism of glomerular deposition of 
immune complexes consisting of HCV, anti-HCV antibodies, and rheumatoid factors. Vasculitis of renal arterioles may also sometimes be present [89].

\section{Hepatitis $C$ in Hemodialysis}

The use of disposable devices, improvements in disinfection techniques for non-disposable items, use of erythropoietin instead of transfusions, and the adherence to standard infection control measures have all led to a decrease in the incidence of HCV infection in patients under regular hemodialysis. However, these transmissions still occur. If so, HCV is usually transmitted from patient to patient via the hands of healthcare workers; therefore, there is a strong need for the application of universal hygiene precautions to avoid such risks. In a Japanese study, investigators observed that some nurses withdrew needles for dialysis access in several consecutive patients without changing their gloves and such an approach resulted in 49 cases of acute HCV infection within a 3-year follow-up [90]. In another study, multi-dose heparin vials shared by patients in a dialysis unit have been suggested as the source of HCV infections [91].

There is no consensus concerning the use of dedicated dialysis machines (and staff) or complete isolation of already infected patients within the dialysis center. Countries with a high initial prevalence of HCV infection have widely used this measure. Most centers argue that the strict application of universal precautions by health staff are more important and sufficient to prevent the $\mathrm{HCV}$ transmission [92-94]. A combination of all of the above factors has decreased both the prevalence (to $<15 \%$ ) and incidence (to $\sim 2.5$ per 100 persons/year), from the 30 $80 \%$ prevalence in the early 1990 s [95]. In the USA, the anti-HCV prevalence among dialysis patients was $10.4 \%$ in 1995, with a decrease to $7.8 \%$ by 2002 [3]. In Europe, the prevalence ranges between 3 and $20 \%[3,96,97]$. The highest HCV prevalences in dialysis patients are still reported from developing countries (e.g. Egypt in 2000 at $80 \%$ or Morocco in 2005 at $76 \%$ ).

As mentioned above, EIA tests are highly sensitive in immunocompetent patients, but in special immunosuppressed populations, such as dialysis patients (or HIV/ HCV co-infection), these tests may be negative despite the presence of an active HCV infection [98]. In a German national study among 3,000 hemodialysis patients, $22 \%$ of HCV-RNA-positive patients were anti-HCV negative on a third-generation test [99]. On the other hand, Fabrizi et al. [93] (also using a third-generation anti-HCV test) found no false-negative serologies in a group of 81 dialysis patients. Therefore, this issue remains controver- sial, and in hemodialysis patients, the PCR tests may be used as a screening procedure for $\mathrm{HCV}$ infection.

Blood sampling for HCV-RNA detection in regular dialysis patients should be strictly performed prior to hemodialysis. Heparin used during the procedure may interfere with PCR detection and cause false-negative results; furthermore, hemodialysis itself is believed to lower viremia, probably due to HCV-RNA adsorption onto the inner surface of dialysis machines, or the direct destruction of virions by the pressure exerted by blood during dialysis [100].

\section{Preventive Measures of HCV Spread in Hemodialysis Units}

There is only one preventive measure against HCV spread within hemodialysis units, and that is the strict adhesion to the general precautions for blood-borne infections. As mentioned above, there is no universal recommendation to provide a hemodialysis procedure for HCV-positive patients in exclusively dedicated rooms or on dialysis machines [101]. The risk of transmission after needlestick injury from an $\mathrm{HCV}$-positive source is rather low $(<2 \%)[49,50]$. Also, there are no recommended measures after exposure. Active vaccination against $\mathrm{HCV}$ is still not available despite very intensive research in this field.

\section{Natural Course of HCV in Hemodialysis and RTR Patients}

$\mathrm{HCV}$ infection in dialysis patients is usually asymptomatic in both the acute and chronic phases. HCV is a slowly progressive disease, with a course typically extending for several decades, but dialysis patients have a much shorter life expectancy. This makes it very difficult to establish the long-term consequences of HCV infection for patients on dialysis as well as for RTRs.

Patients under regular hemodialysis were found to have lower ALT/aspartate transaminase elevations, lower grading and staging in histology, and lower viral load than non-dialyzed individuals in both acute and chronic $\mathrm{HCV}$ infection [102]. A number of factors have been suggested to explain these findings. Likely, immunosuppression, uremia, and dialysis itself may play a role in this controversial issue [103].

Among 37 patients who had undergone a liver biopsy in their evaluation before kidney transplantation, Martin et al. [104] found bridging fibrosis in $8 \%$, and clear-cut cirrhosis in $24 \%$. In this study, a history of alcohol abuse was present in $38 \%$ of the patients, so this could also be responsible for such an incidence of liver cirrhosis. A sim- 
ilar study was published by Sterling et al. [105]. Among 50 patients also waiting for RT, the authors found liver cirrhosis in $22 \%$, which was not significantly different from a control group of HCV-positive patients with intact renal function and normal ALT. Aminotransferase levels were not significantly different between RT candidates and normal ALT controls. In 2 large dialysis registers, the overall prevalence of liver cirrhosis was low (1.5 and 2\%); however, the death rate for patients with cirrhosis was $35 \%$ higher when compared with patients without cirrhosis [106]. To conclude, a significant proportion of patients under regular dialysis may develop advanced liver lesions, even fully developed liver cirrhosis. Therefore, every renal transplant candidate should be evaluated in this respect. Not only liver biopsy may be applied, but also non-invasive tools such as elastography (FibroScan) may be used in such an indication. These non-invasive methods need further studies in dialysis or RT patients, and liver biopsy remains the 'gold standard' for assessing the severity of liver lesions if no clinical signs of apparent liver cirrhosis are present.

To summarize, it has been calculated that HCV increases mortality among dialysis patients with an RR of $1.25-1.57[107,108]$.

Unfortunately, there is a lack of prospective clinical trials evaluating the natural course of HCV after RT with respect to the long-term survival of the recipient or graft. Izopet et al. [109] published an interesting longitudinal trial in which $36 \%$ of 36 RTRs were proven to have progressive liver fibrosis in serial liver biopsies; consequently, liver histologies were deteriorating with the years despite normal (or near normal) ALT levels. In the previously mentioned study by Mathurin et al. [31] in a large group ( $\mathrm{n}=834)$ of RTRs, the authors found significant differences in the survival rates for both recipients and grafts at 10 years, but not at 5 years. HCV-positive patients had lower rates than uninfected matched recipients: 10 -year patient survival was $65 \pm 5$ vs. $85 \pm 3(\mathrm{p}=$ $0.001)$ and $49 \pm 5$ vs. $69 \pm 4 \%$ for graft survival $(\mathrm{p}=0.01)$. In a study by Hanafusa et al. [110], HCV-positive RTRs had a worse survival rate in the 2 nd decade compared with HCV-negative controls. However, there was not any difference in the 10-year survival rate in this study. In a meta-analysis published by Fabrizi et al. [111], the positive anti-HCV status has been confirmed as an independent and significant risk factor for death and graft failure after RT (for death RR: 1.79, 95\% CI 1.57-2.03, and for graft failure RR: 1.56, 95\% CI: 1.35-1.80).

In a certain portion of $\mathrm{HCV}$-positive recipients, $\mathrm{HCV}$ related glomerulonephritis may lead to graft injury and may decrease its function. Berthoux [112] found significantly higher anti-HCV positivity in RTRs with membranous glomerulonephritis and MPGN than in the entire recipient group (78 vs. $29 \%, \mathrm{p}=0.001$ ). HCV infection has also been linked to chronic allograft nephropathy and diabetes mellitus after RT $[113,114]$.

\section{Antiviral Therapy in CKD and Hemodialyzed \\ Patients}

Among the general population, $<1 \%$ of chronically infected patients have spontaneous viral clearance [115]. In CKD or dialysis patients, this is a very unlikely option, which stresses the importance of antiviral treatment in this particular setting. The standard measure of treatment efficacy is the sustained virological response (SVR), defined as being serum HCV-RNA negative 24 weeks after cessation of treatment [28]. The treatment of choice in the general population is the combination of pegylated IFN- $\alpha$ (PEG-IFN) and ribavirin (RBV). This combination leads to SVR in $50-60 \%$ of patients $[116,117]$. SVR correlates with improvements in liver histology, a lower incidence of HCC, and decreased mortality [118-120]. Boceprevir and telaprevir, the first two officially approved members of the directly acting antiviral family, were introduced into the therapy of chronic HCV infection (HCV genotype 1 exclusively) in the non-dialyzed population in 2011. These compounds directly inhibit viral protease activity, which results in the inhibition of the viral replication cycle. Both drugs are combined with PEG-IFN and RBV; such a triple combination reaches the SVR in $\sim 70-80 \%$ of naive patients infected with $\mathrm{HCV}$ genotype $1[121,122]$. These drugs have only been studied in the general population; data on CKD, dialysis, or RTRs are not available at present.

PEG-IFN and RBV have not been studied a great deal in CKD or dialyzed patients. There have been concerns about the potentially dangerous side effects in this particular subgroup of patients, including bone marrow suppression (leukopenia) caused by PEG-IFN and anemia caused by RBV. Therefore, the majority of published clinical trials have either investigated conventional recombinant IFN or PEG-IFN monotherapy. Currently, there are 3 meta-analyses available in the literature which focused on the therapy of chronic HCV infection in dialysis patients. Two of them, published in 2003, found SVR rates of 33 and $37 \%[123,124]$. The third one was published by Gordon et al. [125] in 2008. A systematic literature search resulted in a total of 2,606 abstracts. Only studies describing IFN-based treatment (with or without RBV) in IFNnaive patients have undergone further analysis. Final sta- 
tistical analyses were performed in 25 studies; 20 papers reported the treatment with conventional IFN, and 5 of them reported PEG-IFN-based results. The SVR rates were $19-71 \%$, and the overall SVR rate was $41 \%$ (95\% CI: $33-49)$; in the studies with IFN, the $\chi^{2}$ test showed significant heterogeneity between studies $(\mathrm{p}<0.0001)$. In studies with PEG-IFN monotherapy, SVR rates were 1375\%, with the overall SVR being 37\% (95\% CI: 23-77). Two studies described the combination therapy with PEG-IFN + RBV. One study with 35 enrolled patients had an SVR rate of $97 \%$ after a combination with PEG-IFN $\alpha$ $2 a+R B V$ [126]. The other achieved a SVR rate of $43 \%$ in 14 patients [127]. Adverse events were inconsistently reported, and different studies had used different definitions. Adverse events with a higher prevalence included flu-like symptoms (41\%), anemia (23\%), rejection of a non-functioning kidney allograft (14\%), and depression (10\%). Discontinuation of treatment varied among the studies from 0 to $53 \%$, with an overall rate of $26 \%$ (95\% CI: 20-34). For both of these analyses, the studies showed significant heterogeneity. Based on these results, the authors of this meta-analysis, in summary, recommend that antiviral treatment should be considered in stable $\mathrm{HCV}$-positive patients undergoing hemodialysis, however, with very close and detailed monitoring.

\section{Conclusion}

Major advances have of late been realized in the field of HBV and HCV infection, both in general and high-risk populations. The overall incidence of these infections, as well as the incidence in both dialysis and RT patients (who are traditionally known to be at high risk of HBV/ $\mathrm{HCV}$ exposure) is decreasing at present. Unfortunately, it is still not negligible, especially in less-developed regions. $\mathrm{HBV} / \mathrm{HCV}$ infections still represent a significant cause of morbidity and mortality among CKD patients. These infections have been proven to cause a high incidence of $\mathrm{HCC}$ and liver cirrhosis in this particular population. After RT, the 10-year survival is significantly reduced in $\mathrm{HBV}$ - or $\mathrm{HCV}$-infected patients, mainly due to the high incidence of liver cirrhosis in these patients. Despite the significant advances made in recent years, some controversial issues in the natural course of both infections among both CKD and RTR patients still exist. Therefore, long-term follow-up studies are needed in the near future.

\section{References}

1 Alter MJ, Mast EE: The epidemiology of viral hepatitis in the United States. Gastroenterol Clin North Am 1994;23:437-455.

2 Carey WD: The prevalence and natural history of hepatitis B in the 21st century. Cleve Clin J Med 2009;76(suppl 3):S2-S5.

- 3 Finelli L, Miller JT, Tokars JI, Alter MJ, Arduino MJ: National surveillance of dialysisassociated diseases in the United States, 2002. Semin Dial 2005;18:52-61.

4 Burdick RA, Bragg-Gresham JL, Woods JD, Hedderwick SA, Kurokawa K, Combe C, Saito A, La Bracque J, Port FK, Young EW: Patterns of hepatitis B prevalence and seroconversion in hemodialysis units from three continents: the DOOPS. Kidney Int 2003;63: 2222-2229.

5 Kondili LA, Genovese D, Argentini C, Chionne P, Toscani P, Fabro R, Cocconi R, Rapicetta $\mathrm{M}$ : Nosocomial transmission in simultaneous outbreaks of hepatitis C and B virus infections in a haemodialysis center. Eur J Clin Microbiol Infect Dis 2006;25:527531.
6 Chattopadhyay S, Rao S, Das BC, Singh NP, Kar P: Prevalence of transfusion-transmitted virus infection in patients on maintenance hemodialysis from New Delhi, India. Hemodial Int 2005;9:362-366.

7 Yakaryilmaz F, Gurbuz OA, Guliter S, Mert A, Songur Y, Karakan T, Keles H: Prevalence of occult hepatitis B and hepatitis $C$ virus infections in Turkish hemodialysis patients. Ren Fail 2006;28:729-735.

8 CDC: Recommendations for preventing transmission of infections among chronic hemodialysis patients. MMWR Recomm Rep 2001;50(RR-5):1-43.

9 Hollinger FB, Liang TJ: Hepatitis B virus; in Knipe DM, Howley PM, Chanock RM, Monath TP, Roizman B, Straus SE (eds): Field's Virology, ed 4. Philadelphia, Lippincott-Raven, 2000, pp 2971-3036.

10 Dryden KA, Wieland SF, Whitten-Bauer C, Gerin JL, Chisari FV, Yeager M: Native hepatitis B virions and capsids visualized by electron cryomicroscopy. Mol Cell 2006;22:843850.

-11 Magnius LO, Norder H: Subtypes, genotypes and molecular epidemiology of the hepatitis $B$ virus as reflected by sequence variability of the S-gene. Intervirology 1995;38:24-34.
12 Chu C-J, Keeffe EB, Han S-H, Perrillo RP, Min AD, Soldevila-Pico C, et al, US HBV Epidemiology Study Group: Hepatitis B virus genotypes in the United States: results of a nationwide study. Gastroenterology 2003; 125:444-451.

13 Kao JH, Chen PJ, Lai MY, Chen DS: Hepatitis $B$ genotypes correlate with clinical outcomes in patients with chronic hepatitis B. Gastroenteroloogy 2000;118:554-559.

$\checkmark 14$ Hoofnagle JH, Doo E, Liang J, Fleischer R, Lok ASF: Management of hepatitis B: summary of a clinical research workshop. Hepatology 2007;45:1056-1075.

15 Chisari FV, Ferrari C: Hepatitis B virus immunopathogenesis. Annu Rev Immunol 1995; 13:29-60.

- 16 Cote PJ, Korba BE, Miller RH, Jacob JR, Baldwin $\mathrm{BH}$, Horbuckle WE, Purcell RH, Tennant BC, Gerin JL: Effects of age and virus determinants on chronicity as an outcome of experimental woodchuck hepatitis virus infection. Hepatology 2000;31:190200.

17 Fabrizi F, Messa P, Martin P: Hepatitis B virus infection and the dialysis patient. Semin Dial 2008;5:440-446. 
18 Liaw YF, Chia-Ming Chu: Hepatitis B virus infection. Lancet 2009;373:582-592.

-19 Rychlík I, Petrtýl J, Tesar V, Stejskalová A, Zabka J, Brůha R: Transjugular renal biopsy. Our experience with 67 cases. Kidney Blood Press Res 2001;24:207-212.

20 Marcelli D, Stanhard D, Conte F, Held PJ, Locatelli F, Port FK: ESRD patient mortality with adjustment for comorbid conditions in Lombardy (Italy) versus the United States. Kidney Int 1996;50:1013-1018.

-21 Marzano A, Angelucci E, Andreone P, Brunetto M, Bruno R, Burra P, Caraceni P, Daniele B, Di Marco V, Fabrizi F, Fagiuoli S, Grossi P, Lampertico P, Meliconi R, Mangia A, Puoti M, Raimondo G, Smedile A, Italian Association for the Study of the Liver (AISF): Prophylaxis and treatment of hepatitis B in immunocompromised patients. Dig Liver Dis 2007;39:397-408.

22 Maisonneuve P, Agodoa L, Gellert R, Stewart JH, Buccianti G, Lowenfels AB, Wolfe RA, Jones E, Disney AP, Briggs D, McCredkie M, Boyle P: Cancer in patients on dialysis for end-stage renal disease: an international and collaborative study. Lancet 1999;354:93-99.

$\checkmark 23$ Fornairon S, Pol S, Legendre C, Carnot F, Mamzer-Bruneel MF, Brechot C, Kreis H: The long-term virologic and pathologic impact of renal transplantation on chronic hepatitis $B$ virus infection. Transplantation 1996;62:297-299.

-24 Degos F, Lugassy C, Degott C, Debure A, Carnot F, Theirs V, Tiollais P, Kreis H, Brechot C: Hepatitis B virus and hepatitis B-related viral infection in renal transplant recipients. A prospective study of 90 patients. Gastroenterology 1988;94:151-156.

$\checkmark 25$ Tsai M-C, Chen C-H, Lee C-M, Chen Y-T, Chien Y-S, Hung C-H, Wang J-H, Lu S-N, Yen Y-H, Changchien C-S, Hu T-H: The role of HBV genotype, core promoter and precore mutations in advanced liver disease in renal transplant recipients. J Hepatol 2009;50:281288.

-26 Aroldi A, Lampertico P, Montagnino G, Passerini $P$, Villa $M$, Campise $M$, Lungi $G$, Tarantino $\mathrm{A}$, Cesana $\mathrm{B}$, Messa $\mathrm{P}$, Ponticelli C: Natural history of hepatitis B and C in renal allograft recipients. Transplantation 2005;9: 1132-1136.

-27 Blanpain C, Knoop C, Delforge ML, Antoine M, Peny MO, Liesnard C, Vereerstraeten P, Cogan E, Adler M, Abramowicz D: Reactivation of hepatitis B after transplantation in patients with pre-existing anti-hepatitis $B$ surface antigen antibodies: report on three cases and review of the literature. Transplantation 1998;66:883-886.

28 European Association for the Study of the Liver: EASL Clinical Practice Guidelines: Management of chronic hepatitis B. J Hepatol 2009;50:227-242.
29 Rivolta E, De Vecchi A, Tarantino A, Castelnovo C, Berardinelli L, Ponticelli C: Prognostic significance of hepatitis B surface antigenemia in cadaveric renal transplant patients. Transplant Proc 1987;19:2153-2154.

-30 Huang CC, Lai MK, Fong MT: Hepatitis B liver disease in cyclosporine-treated renal allograft recipients. Transplantation 1990;49: 540-544.

-31 Mathurin P, Mouquet C, Poynard T, Sylla C, Benalia H, Fretz C, Thibault V, Cadranel JF, Bernard B, Opolon P, Coriat P, Bitker MO: Impact of hepatitis $B$ and $C$ virus on kidney transplantation outcome. Hepatology 1999; 29:257-263.

32 Lee WC, Shu KH, Cheng CH, Wu MJ, Chen $\mathrm{CH}$, Lian JC: Long-term impact of hepatitis $\mathrm{B}, \mathrm{C}$ virus infection on renal transplantation. Am J Nephrol 2001;21:300-306.

- 33 Fabrizi F, Martin P, Dixit V, Kanwal F, Dulai G: HBsAg seropositive status and survival after renal transplantation: meta-analysis of observational studies. Am J Transplant 2005; 5:2913-2921.

34 Chen CJ, Yang HI, Iloeje UH, REVEALHBV Study Group: Hepatitis B virus DNA levels and outcomes in chronic hepatitis B. Hepatology 2009;49(suppl 5):S72-S84.

35 Preikschat P, Gunther S, Reinhold S, Will H, Budde K, Neumayer HH, Kruger DH, Meisel $\mathrm{H}$ : Complex HBV populations with mutations in core promoter, $\mathrm{C}$ gene, and pre- $\mathrm{S}$ region are associated with development of cirrhosis in long-term renal transplant recipients. Hepatology 2002;35:466-477.

- 36 Fabrizi F, Messa P, Basile C, Martin P: Hepatic disorders in chronic kidney disease. Nat Rev Nephrol 2010;7:395-403.

37 Eleftheriadis T, Antoniadi G, Liakopoulos V, Kartsios C, Stefanidis I: Disturbances of acquired immunity in hemodialysis patients. Semin Dial 2007;5:440-451.

38 Eleftheriadis T, Papazisis K, Kortsaris A, Vayonas G, Voyatzi S, Vargemezis V: Impaired $\mathrm{T}$ cell proliferation and zeta chain phosphorylation after stimulation with staphylococcal enterotoxin-B in hemodialysis patients. Nephron Clin Pract 2004;1:1520.

39 Girndt M, Kaul H, Leitnaker CK, Sester M, Sester U, Köhler H: Selective sequestration of cytokine-producing monocytes during hemodialysis treatment. Am J Kidney Dis 2001; 5:954-963.

40 Girndt M, Sester M, Sester U, Kaul H, Köhler $\mathrm{H}$ : Defective expression of B7-2 (CD86) on monocytes of dialysis patients correlates to the uremia-associated immune defect. Kidney Int 2001;4:1382-1389.

41 Girndt M, Sester M, Sester U, Kaul H, Köhler $\mathrm{H}$ : Molecular aspects of T- and B-cell function in uremia (review). Kidney Int Suppl 2001;78:S206-S211.
42 Contin C, Pitard V, Delmas Y, Pelletier N, Defrance T, Moreau JF, Merville P, DéchanetMerville J: Potential role of soluble CD40 in the humoral immune response impairment of uraemic patients. Immunology 2003;110: 131-140.

43 Ori Y, Korzets A, Malachi T, Gafter U, Breitbart H: Impaired lymphocyte calcium metabolism in end-stage renal disease: enhanced influx, decreased efflux, and reduced response to mitogen. J Lab Clin Med 1999;4: 391-400.

44 Sester U, Sester M, Hauk M, Kaul H, Köhler $\mathrm{H}$, Girndt M: T-cell activation follows Th1 rather than Th2 pattern in haemodialysis patients. Nephrol Dial Transplant 2000;8: 1217-1223.

45 Meier P, Dayer E, Blanc E, Wauters JP: Early T cell activation correlates with expression of apoptosis markers in patients with end-stage renal disease. J Am Soc Nephrol 2002;13: 204-212.

46 Tokars JI, Finelli L, Alter MJ, Arduino MJ: National surveillance of dialysis-associated diseases in the United States, 2001. Semin Dial 2004;17:310-319.

47 Bond WW, Favero MS, Petersen NJ, Gravelle CR, Ebert JW, Maynard JE: Survival of hepatitis $B$ virus after drying and storage for one week. Lancet 1981;i:550-551.

48 Kamili S, Krawczynski K, McCaustland K, Li $\mathrm{X}$, Alter MJ: Infectivity of hepatitis $\mathrm{C}$ virus in plasma after drying and storing at room temperature. Infect Control Hosp Epidemiol 2007;28:519-524.

49 Beltrami EM, Williams IT, Shapiro CN, Chamerland ME: Risk and management of blood-borne infections in health care workers. Clin Mircrobiol Rev 2000;13:385-407.

50 Updated U.S. Public Health Service Guidelines for the Management of Occupational Exposures to HBV, HCV, and HIV and Recommendations for Postexposure Prophylaxis. MMWR Recomm Rep 2001;50(RR-11):152.

51 Miller ER, Alter MJ, Tokars JI: Protective effect of hepatitis B vaccine in chronic hemodialysed patients. Am J Kidney Dis 1999;33: 356-360.

52 Girndt M, Kohler H: Hepatitis B virus infection in hemodialysed patients. Semin Nephrol 2002;22:340-350.

53 Lombardi M, Pizzarelli F, Righi M, Cerrai T, Dattolo P, Nigrelli S, Michelassi S, Sisca S, Alecci A, Di Geronimo P, et al: Hepatitis B vaccination in dialysis patients and nutritional status. Nephron 1992;61:266-268.

54 Sester U, Sester M, Hauk M, Kaul H, Köhler H, Girndt M: T-cell activation follows Th1 rather than Th2 pattern in haemodialysis patient. Nephrol Dial Transplant 2000;15: 1217-1223. 
-55 Eleftheriadis T, Liakopoulos V, Antoniadi G, Stefanidis I, Galaktidou G: Indoleamine 2,3-dioxygenase is increased in hemodialysis patients and affects immune response to hepatitis B vaccination. Vaccine 2011;12: 2242-2247.

-56 Sezer S, Ozdemir FN, Guz G, Arat Z, Colak T, Sengul S, Turan M, Haberal A, Erdal R: Factors influencing response to hepatitis $\mathrm{B}$ virus vaccination in hemodialysis patients. Transplant Proc 2000;32:607-608.

57 Vagelli G, Calabrese G, Mazzotta A, Pratesi G, Gonella M: More about response to hepatitis B vaccine in hemodialysis patients. Nephron 1988;49:171.

-58 Navarro JF, Teruel JL, Mateos ML, Marcen $\mathrm{R}$, Ortuno J: Antibody level after hepatitis B vaccination in hemodialysis patients: influence of hepatitis C virus infection. Am J Nephrol 1996;16:95-97.

-59 Pozzilli P, Arduini P, Visalli N, Sutherland J, Pezzella M, Galli C, Corradini SG, Biasio L, Gale EA, Andreani D: Reduced protection against hepatitis $B$ virus following vaccination in patients with type 1 (insulin-dependent) diabetes. Diabetologia 1987;30:817819.

-60 DaRoza G, Loewen A, Djurdjev O, Love J, Kempston C, Burnett S, Kiaii M, Taylor PA, Levin A: Stage of chronic kidney disease predicts seroconversion after hepatitis B immunization. Earlier is better. Am J Kidney Dis 2003;42:1184-1192.

-61 Fabrizi F, Di Filippo S, Marcelli D, Guarnori I, Raffaele L, Crepaldi M, Erba G, Locatelli F: Recombinant hepatitis $B$ vaccine use in chronic hemodialysis patients. Long-term evaluation and cost-effectiveness analysis. Nephron 1996;72:536-543.

-62 Dinits-Pensy M, Forrest GN, Cross AS, Hise MK: The use of vaccine in adult patients with renal disease. Am J Kidney Dis 2005;46:9971011.

-63 Tsouchnikas I, Dounousi E, Xanthopoulou K, Papakonstantinou S, Thomoglou V, Tsakiris D: Loss of hepatitis B immunity in hemodialysis patients acquired either naturally or after vaccination. Clin Nephrol 2007;68: 228-234.

64 Lok ASF, McMahon BJ: Chronic hepatitis B. Hepatology 2007;45:507-539.

65 Blum HE: Hepatitis B virus: significance of naturally occurring mutants. Intervirology 1993;35:40-50.

- 66 Keeffe EB, Dieterich DT, Han SH, Jacobson IM, Martin P, Schiff ER, Tobias H, Wright TL: A treatment algorithm for the management of chronic hepatitis B virus infection in the United States: an update. Clin Gastroenterol Hepatol 2006;4:936-962.

67 Gane E, Pilmore H: Management of chronic viral hepatitis before and after renal transplantation. Transplantation 2002;74:427437.

68 EASL Clinical Practice Guidelines: Management of chronic hepatitis B. J Hepatol 2009; 50:227-242.
69 Fontaine H, Thiers V, Chrétien Y, Zylberberg $\mathrm{H}$, Poupon RE, Bréchot C, Legendre C, Kreis $\mathrm{H}$, Pol S: HBV genotypic resistance to lamivudine in kidney recipients and hemodialyzed patients. Transplantation. 2000;10: 2090-2094.

70 Joh JW, Lee HH, Park JW, Lee DH, Yoo BC, Lee KW, Kim SJ: Genotypic resistance of hepatitis $\mathrm{B}$ virus to lamivudine in renal transplant recipients. Transplant Proc 2005; 2:1235-1237.

71 Choo QL, Kuo G, Weiner AL, Overby LR, Bradley DW, Houghton M: Isolation of a cDNA clone derived from a blood-borne non-A, non-B viral hepatitis genome. Science 1989;244:359-362.

72 Alter MJ: Epidemiology of hepatitis C virus. World J Gastroenterol 2007;13:2436-2441.

73 Frank C, Mohamed MK, Strickland GT, Lavanchy D, Arthur RR, Magder LS, El Khoby T, Abdel-Wahab Y, Aly Ohn ES, Anwar W, Sallam I: The role of parenteral antischistosomal therapy in the spread of hepatitis $\mathrm{C}$ virus in Egypt. Lancet 2000;355:887-891.

74 Moradpour D, Penin F, Rice CM: Replication of hepatitis C virus. Nat Rev Microbiol 2007; 5:453-463.

75 Esteban JI, Sauleda S, Quer J: The changing epidemiology of hepatitis $\mathrm{C}$ virus infection in Europe. J Hepatol 2008;48:148-162.

76 Rustgi VK: The epidemiology of hepatitis C infection in the United States. J Gastroenterol 2007;42:513-521.

77 Bialek SR, Terrault NA: The changing epidemiology and natural history of hepatitis $\mathrm{C}$ virus infection. Clin Liver Dis 2006; 144:762769.

78 Pawlotsky JM, Bouvier-Alias M, Hezode C, Darthuy F, Remire J, Dhumeaux D: Standardization of hepatitis $C$ virus RNA quantification. Hepatology 2000;32:654-659.

79 Lunel F, Musset L, Cacoub P, Frangeul L, Cresta P, Perrin M, et al: Cryoglobulinemia in chronic liver diseases: role of hepatitis $\mathrm{C}$ virus and liver damage. Gastroenterology 1994;106:1291-1300.

80 Dammacco F, Sansonno D, Piccoli C, Racanelli V, D'Amore FP, Lauletta G: The lymphoid system in heaptitis $C$ virus infection: autoimmunity, mixed cryoglobulinemia and overt B-cell malignancy (review). Semin Liver Dis 2000;20:143-157.

81 Monti G, Galli M, Invernizzi F, Pioltelli P, Saccardo F, Monteverde A: Cryoglobulinaemias: a multi-centre study of the early clinical and laboratory manifestations of primary and secondary disease. GISC. Italian Group for the Study of Cryoglobulinaemias. QJM 1995;88:115-126.

82 Lunel F, Musset L: Mixed cryoglobulinemia and hepatitis $\mathrm{C}$ virus infection (review). Minerva Med 2001;92:35-42.

83 Kayali Z, Buckwold VE, Zimmerman B, Schmidt WN: Hepatitis C, cryoglobulinemia, and cirrhosis: a meta-analysis. Hepatology 2002;36:978-985.
84 Arase Y, Ikeda K, Murashima N, et al: Glomerulonephritis in autopsy cases with hepatitis C virus infection. Intern Med 1998;37: 836-840.

85 Bandi L: Renal manifestations of hepatitis C virus infection. Extrahepatic complications often are silent - and thus overlooked. Postgrad Med 2003;113:73-76.

86 Yamabe H, Johnson RJ, Gretch DR, et al: Hepatitis $\mathrm{C}$ virus infection and membranoproliferative glomerulonephritis in Japan. J Am Soc Nephrol 1995;6:220-223.

87 D’Amico G, Fornasieri A: Cryoglobulinemic glomerulonephritis: a membranoproliferative glomerulonephritis induced by hepatitis C virus. Am J Kidney Dis 1995;25:361-369.

-88 Johnson RJ, Gretch DR, Yamabe H, Hart J, Bacchi CE, Hartwell P, Couser WG, Corey L, Wener MH, Alpers CE: Membranoproliferative glomerulonephritis associated with hepatitis C virus infection. N Engl J Med 1993; 328:465-470.

89 Agnello V, De Rosa F: Extrahepatic disease manifestations of HCV infection: some current issues. J Hepatol 2004;40:341-352.

90 Okuda KH, Hayashi H, Kobayashi S, Irie Y: Mode of hepatitis $\mathrm{C}$ infection not associated with blood transfusions among chronic haemodialysis patients. J Hepatol 1995;23:2831.

91 Kokubo S, Horii T, Yonekawa O, Ozawa N, Mukaide M: A phylogenetic-tree analysis elucidating nosocomial transmission of hepatitis $\mathrm{C}$ virus in a haemodialysis unit. J Viral Hepat 2002;9:450-454.

92 Recommendations for prevention and control of hepatitis $\mathrm{C}$ virus (HCV) infection and HCV-related chronic disease. Centers for Disease Control and Prevention. MMWR Recomm Rep 1998;47:1-39.

93 Fabrizi F, Poordad F, Martin P: Hepatitis C infection and the patient with end stage renal disease. Hepatology 2002;36:3-10.

$\$ 94$ Froio N, Nicastri E, Comandini UV, Cherubini C, Felicioni R, Solmone M, Di Giulio S, Petrosillo N: Contamination by hepatitis $\mathrm{B}$ and $\mathrm{C}$ viruses in the dialysis setting. Am J Kidney Dis 2003;42:546-550.

95 Shepard CW, Finelli L, Alter MJ: Global epidemiology of hepatitis $C$ virus infection. Lancet Infect Dis 2005;5:558-567.

96 Fissell RB, Bragg-Gresham JI, Woods JD, Jadoul M, Gillespie B, Hedderwick SA, Rayner HC, Greenwood RN, Akiba T, Young EW: Patterns of hepatitis $\mathrm{C}$ prevalence and seroconversion in hemodialysis units from three continents: the DOOPS. Kidney Int 2004;65:2335-2342.

\$97 Jadoul M, Poignet JL, Geddes C, Locatelli F, Medin C, Krajewska M, Barril G, Scheuermann E, Sonkodi S, Goubau P, HCV Collaborative Group: The changing epidemiology of hepatitis $\mathrm{C}$ virus infection in hemodialysis: European multicentre study. Nephrol Dial Transplant 2004;19:904-909. 
98 Thio CL, Nolt KR, Astemborski J, Vlahov D, Nelson KE, Thomas DL: Screening for hepatitis $\mathrm{C}$ virus in human immnodeficiency virus-infected individuals. J Clin Microbiol 2000;38:575-577.

99 Hinrichsen H, Leimenstoll G, Steen G, Schrader H, Folsch UR, Schmidt WE: Prevalence and risk factors of hepatitis $\mathrm{C}$ virus infection in haemodialysis patients: a multicentre study in 2796 patients. Gut 2002;51: 429-433.

100 Okuda K, Hayashi J, Yokozeki K, Irie Y: Destruction of hepatitis $C$ virus particles by hemodialysis (letter). Lancet 1999;347: 909-910.

101 Guideline 3: preventing HCV transmission in hemodialysis units. Kidney Int 2008; 73:S46-S52.

-102 Rampino T, Arbustini E, Gregorini M, Guallini P, Libetta C, Maggio M, Ranghino A, Silini E, Soccio G, Dal Canton A: Hemodialysis prevents liver disease caused by hepatitis $\mathrm{C}$ virus: role of hepatocyte growth factor. Kidney Int 1999;56:2286-2291.

103 Fabrizi F, Lunghi G, Finazzi S, Colucci P, Pagano A, Ponticelli C, Locatelli F: Decreased serum aminotransferase activity in patients with chronic renal failure: impact of the detection of viral hepatitis. Am J Kidney Dis 2001;38:1009-1015.

104 Martin P, Carter D, Fabrizi F, Dixit V, Conrad AJ, Artinian L, Peacock V, Han S, Wilkinson A, Lassman CR, Danovitch G: Histopathological features of hepatitis $\mathrm{C}$ in renal transplant candidates. Transplantation 2000;69:1479-1484.

-105 Sterling RK, Sanyal AJ, Luketic VA, Stravitz RT, King AL, Post AB, Mills SA, Contos MJ, Shiffman ML: Chronic hepatitis C infection in patients with end stage renal disease: characterization of liver histology and viral load in patients awaiting renal transplantation. Am J Gastroenterol 1999;94;35763582.

106 Simon N, Courouce AM, Lemarrec N, Trepo C, Ducamp S: A twelve year natural history of hepatitis $\mathrm{C}$ virus infection in hemodialyzed patients. Kidney Int 1994;46:504511.

-107 Fabrizi F, Martin P, Dixit V, Bunnapradist S, Dulai G: Meta-analysis: effect of hepatitis $\mathrm{C}$ virus infection on mortality in dialysis. Aliment Pharmacol Ther 2004;20:12711277.

108 Kalantar-Zadeh K, Kilpatrick RD, McAllister CJ, Miller LG, Daar ES, Gjertson DW, Kopple JD, Greenland S: Hepatitis C virus and death risk in hemodialysis patients. J Am Soc Nephrol 2007;18:1584-1593.
109 Izopet J, Rostaing L, Sandres K, Cisterne JM, Pasquier C, Rumeau JL, Duffault M, Durand D, Puel J: Longitudinal analysis of hepatitis $\mathrm{C}$ virus replication and liver fibrosis progression in renal transplant recipients. J Infect Dis 2000;181:852-858.

110 Hanafusa T, Ichikawa Y, Kishikawa H, Kyo M, Fukunishi T, Kokado Y, Okuyama A, Shinji Y, Nagano S: Retrospective study on the impact of hepatitis $C$ virus infection on kidney transplant patients over 20 years. Transplantation 1998;66:471-476.

111 Fabrizi F, Martin P, Dixit V, Bunnapradist S, Dulai G: Hepatitis C virus antibody status and survival after renal transplantation: meta-analysis of observational studies. Am J Transplant 2005;5:1452-1461.

112 Berthoux F: Hepatitis C virus infection and disease in renal transplantation. Nephron 1995;71:386-394.

113 Mahmoud IM, Sobh MA, El-Habashi AF, Sally ST, El-Baz M, El-Sawy E, Ghoneim MA: Interferon therapy in hemodialysis patients with chronic hepatitis C: study of tolerance, efficacy and posttransplantation course. Nephron Clin Pract 2005;100:c133c139.

114 Abbott KC, Lentine KL, Bucci JR, Agodoa LY, Koff JM, Holtzmuller KC, Schnitzler MA: Impact of diabetes and hepatitis after kidney transplantation on patients who are affected by hepatitis $\mathrm{C}$ virus. J Am Soc Nephrol 2004;15:3166-3174.

115 Watanabe H, Saito T, Shinzawa H, Okumoto K, Hattori E, Adachi T, Takeda T, Sugahara K, Ito JI, Saito K, Togashi H, Suzuki R, Hayashi M, Miyamura T, Matsuura Y, Kawata S: Spontaneous elimination of serum hepatitis C virus (HCV) RNA in chronic HCV carriers: a population-based cohort study. J Med Virol 2003;1:56-61.

116 Manns MP, McHutchison JG, Gordon SC, Rustgi VK, Shiffman M, Reindollar R, Goodman ZD, Koury K, Ling M, Albrecht JK: Peginterferon alfa-2b plus ribavirin compared with interferon alfa- $2 \mathrm{~b}$ plus ribavirin for initial treatment of chronic hepatitis C: a randomised trial. Lancet 2001;358: 958-965.

117 Fried MW, Shiffman ML, Reddy KR, Smith C, Marinos G, Gonçales FL Jr, Häussinger D, Diago M, Carosi G, Dhumeaux D, Craxi A, Lin A, Hoffman J, Yu J: Peginterferon alfa-2a plus ribavirin for chronic hepatitis C virus infection. N Engl J Med 2002;13: 975-982.

118 Marcellin P, Boyer N, Gervais A, Martinot M, Pouteau M, Castelnau C, Kilani A, Areias J, Auperin A, Benhamou JP, Degott C, Erlinger S: Long-term histologic improvement and loss of detectable intrahepatic HCV RNA in patients with chronic hepatitis $\mathrm{C}$ and sustained response to interferon-alpha therapy. Ann Intern Med 1997; 10:875-881.
19 Bruno S, Battezzati PM, Bellati G, Manzin A, Maggioni M, Crosignani A, Borzio $M$, Solforosi L, Morabito A, Ideo G, Podda M: Long-term beneficial effects in sustained responders to interferon-alfa therapy for chronic hepatitis C. J Hepatol 2001;5:748755.

120 Yoshida H, Arakawa Y, Sata M, Nishiguchi S, Yano M, Fujiyama S, Yamada G, Yokosuka O, Shiratori Y, Omata M: Interferon therapy prolonged life expectancy among chronic hepatitis C patients. Gastroenterology 2002;2:483-491.

121 Poordad F, McCone J Jr, Bacon BR, Bruno S, Manns MP, Sulkowski MS, Jacobson IM, Reddy KR, Goodman ZD, Boparai N, DiNubile MJ, Sniukiene V, Brass CA, Albrecht JK, Bronowicki JP, SPRINT-2 Investigators: Boceprevir for untreated chronic HCV genotype 1 infection. N Engl J Med 2011;13: 1195-1206.

122 Jacobson IM, McHutchison JG, Dusheiko G, Di Bisceglie AM, Reddy KR, Bzowej NH, Marcellin P, Muir AJ, Ferenci P, Flisiak R, George J, Rizzetto M, Shouval D, Sola R, Terg RA, Yoshida EM, Adda N, Bengtsson L, Sankoh AJ, Kieffer TL, George S, Kauffman RS, Zeuzem S, ADVANCE Study Team: Telaprevir for previously untreated chronic hepatitis $\mathrm{C}$ virus infection. N Engl J Med 2011;25:2405-2416.

123 Fabrizi F, Dulai G, Dixit V, Bunnapradist S, Martin P: Meta-analysis: interferon for the treatment of chronic hepatitis $\mathrm{C}$ in dialysis patients. Aliment Pharmacol Ther 2003;18: 1071-1081.

124 Russo MW, Goldsweig CD, Jacobson IM, Brown RS Jr: Interferon monotherapy for dialysis patients with chronic hepatitis C: an analysis of the literature on efficacy and safety (review). Am J Gastroenterol 2003;7: 1610-1615.

125 Gordon CE, Uhlig K, Lau J, Schmid CH, Levey AS, Wong JB: Interferon treatment in hemodialysis patients with chronic hepatitis $C$ virus infection: a systematic review of the literature and meta-analysis of treatment efficacy and harms (review). Am J Kidney Dis 2008;2:263-277.

126 Rendina M, Schena A, Castellaneta NM, Losito F, Amoruso AC, Stallone G, Schena FP, Di Leo A, Francavilla A: The treatment of chronic hepatitis $\mathrm{C}$ with peginterferon alfa-2a $(40 \mathrm{kDa})$ plus ribavirin in haemodialysed patients awaiting renal transplant. J Hepatol 2007;5:768-774.

127 Deltenre V, Canva F, Provot F, et al: Pegylated interferon and ribavirin in haemodialyzed patients with chronic hepatitis $\mathrm{C}$ : a prospective study (abstract). Hepatology 2006;44(suppl 1):S329A. 